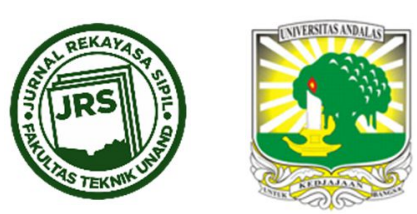

\title{
ANALISIS PENGARUH KONFIGURASI MENARA PADA JEMBATAN CABLE STAYED AKIBAT BEBAN GEMPA
}

\author{
YESSI STANI BEATA SIAHAAN ${ }^{*}$, RELLY ANDAYANI $^{2}$ \\ ${ }^{1}$ Magister Teknik Sipil, Program Pasca Sarjana, Universitas Gunadarma, Tanggerang, Banten, Indonesia \\ 2Jurusan Teknik Sipil, Fakultas Teknik Sipil \& Perencanaan, Universitas Gunadarma, Tanggerang, Banten, \\ Indonesia \\ *Corresponding author: $ه$ yessi.siahaan76@gmail.com
}

Naskah diterima : 9 Januari 2021. Disetujui: 04 Februari 2021

\begin{abstract}
ABSTRAK
Perkembangan teknologi jembatan cable stayed khususnya untuk jembatan bentang panjang berkembang sangat pesat. Jembatan cable stayed merupakan pilihan yang tepat karena desain geometri struktur yang relatif ringan, ekonomis dan lebih kaku dibandingkan dengan jembatan gantung. Analisis beban gempa yang terjadi dalam perhitungan struktur jembatan cable stayed sangat penting, karena sistem menara jembatan bersentuhan langsung dengan tanah keras sebagai media pelepasan energi sesaat saat terjadi gempa bumi. Tujuan dari penelitian ini untuk menganalisis struktur menara jembatan cablye stayed dengan konfigurasi bentuk menara jembatan yang berbeda dalam memikul beban akibat beban gempa sehingga didapatkan bentuk menara yang memiliki gaya dalam minimum. Perencanaan bentuk menara bervariasi antara lain menara tipe A, menara tipe $\mathrm{H}$, menara tipe berlian, menara tipe inverted Y, dan menara tipe X. Penyusunan kabel menggunakan Konfigurasi Semi Fan dan metode analisis dinamis menggunakan Time History Analysis. Bentuk struktur jembatan menara cable stayed sangat mempengaruhi kinerja dari struktur jembatan secara keseluruhan karena menara merupakan komponen utama jembatan yang menenerima gaya tekan dan momen yang besar. Hasil analisis diperoleh menara yang mengalami perpindahan minimum adalah menara tipe Inverted Y. Hasil analisis diperoleh semakin banyak tarikan kabel yang ditopang menara, semakin sedikit tumpuan pada menara dan geometri pada puncak menara yang tidak menyatu maka semakin besar gaya-gaya dalam yang dialami menara. Menara yang mengalami gayagaya dalam yang minimum yang dapat direkomendasi untuk digunakan pada jembatan cable stayed adalah menara tipe A, tipe $\mathrm{H}$ dan tipe Inverted Y.
\end{abstract}

Kata kunci : Jembatan Cable Stayed; Menara; Gaya-Gaya Dalam; Time History Analysis; CSI Bridge

\section{PENDAhULUAN}

Jembatan cable stayed merupakan salah satu jembatan yang populer di Indonesia karena desain geometri struktur yang relatif ringan, ekonomis dan lebih kaku dibandingkan dengan jembatan gantung. Karakteristik gempa yang terjadi di wilayah Indonesia akan

DOI : https://doi.org/10.25077/jrs.17.1.37-51.2021

Attribution-NonCommercial 4.0 International. Some rights reserved 
mempengaruhi proses perencanaan struktur jembatan cable stayed di setiap wilayahnya. Analisis beban gempa yang terjadi dalam perhitungan struktur jembatan cable stayed sangat penting, karena sistem menara jembatan bersentuhan langsung dengan tanah keras sebagai media pelepasan energi sesaat saat terjadi gempa bumi. (Mukhsin \& Ramdani, 2017)

Jembatan cable stayed dibangun dengan berbagai bentuk menara seperti menara tipe $\mathrm{H}$, tipe A,tipe berlian, tipe Inverted $\mathrm{Y}$ dan lain sebagainya. Hal ini menyebabkan banyaknya permintaan untuk mengevaluasi efek dari berbagai bentuk menara pada jembatan cable stayed. Fungsi dari menara adalah mendukung gaya dari kabel dan mentransfer gayanya menuju pondasi, dengan menahan gaya tekan yang tinggi dan gaya momen yang tergantung dari susunan kabel dan kondisi hubungan menara dengan gelagar. Respons dinamik pada menara akan terkondisikan oleh beberapa aspek salah satunya adalah bentuk geometrinya. Hal ini tergantung juga oleh pembebanan yang diterapkan, sistem kabel dan kondisi estetikanya.(Hararwala \& Maaru, 2016). Perpindahan dan respon momen pada menara dapat diminimumkan karena pengaruh SSI (Soil Structure Interaction) yang dominan untuk kondisi tanah lunak dan meningkatkan periode dasar pada semua bentuk menara akibat gempa bumi. Bentuk menara memiliki pengaruh besar dalam mitigasi terhadap hasil pengaruh SSI yang menunjukan bahwa perbandingan menara tipe $\mathrm{A}$ atau tipe $\mathrm{H}$ memberikan respon minimum (Shah et al., 2010). Pengaturan susunan kabel menggunakan sistem semifan memiliki respon yang lebih baik dibandingkan penyusunan sistem harp dan sistem fan pada jembatan cable stayed. (Zadeh, 2012)

Analisis dan perencanaan struktur jembatan cable stayed ini untuk mengevaluasi pengaruh konfigurasi menara terhadap gempa dengan menggunakan pemodelan struktur tiga dimensi pada kondisi tanah keras dengan mengambil lokasi penelitian di Kalimantan Timur. Analisis menggunakan sistem kabel semifan karena memiliki nilai lendutan yang minimum, jumlah kabel yang lebih sedikit dibandingkan tipe harp, serta metode pemasangan kabel pada menara bagian atas tidak rumit. Analisis menggunakan software aplikasi CSI Bridge dalam mengoptimasikan bentuk geometri struktur jembatan kabel stayed akibat beban gempa statik dan dinamik dengan dukungan data perancangan yang sesuai dengan peraturan yang berlaku, sehingga diperoleh konfigurasi struktur jembatan yang memiliki lendutan dan gaya-gaya dalam minimum sebagai rekomendasi.

\subsection{Konsep Cable Stay Bridge}

Jembatan cable stayed merupakan salah satu bentuk jembatan yang sering digunakan dengan kemampuannya mengatasi bentang yang panjang (Gambar 1), dengan bentang yang dapat dicapai adalah empat kali bentang gelagar sederhana bila dimensi dipertahankan(Irawan \& Tristanto, 2011). Kekhususan jembatan ditandai dengan daya tarik estetika yang simpel dan tampak elegan, penggunaan material struktur secara efisien, kecepatan kerja konstruksinya, dan dimensi elemen strukturalnya relatif semakin kecil. Jembatan cable stayed modern memberikan sistem struktur tiga dimensi yang terdiri dari girder, deck, menara, kabel dan angkur (Mukhsin \& Ramdani, 2017). 


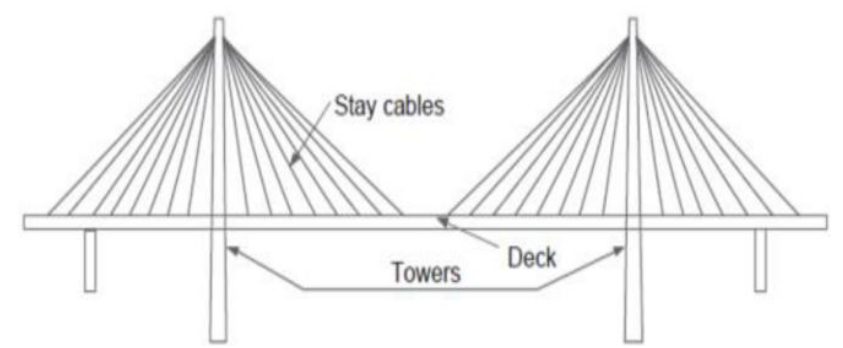

Gambar 1. Skema Jembatan Cable Stayed (Ohorella \& Harsoyo, 2017)

Kabel merupakan bagian jembatan cable-stayed yang menahan gaya tarik (Gambar 2). Kabel stay juga berfungsi sebagai perancah dalam pemasangan gelagar lantai dengan sistem kantilever bertahap dan sebagai perletakan elastis/pegas atau pilar antara dalam struktur akhir. Pemilihan jumlah dan susunan kabel berpengaruh terhadap dimensi gelagar dan menara serta metode pelaksanaan struktur jembatan cable-stayed. Sistem penataan kabel dapat dibedakan menjadi tiga jenis antara lain sistem sejajar (harp) dimana kabel dipasang sejajar dan disambungkan ke menara dengan ketinggian yang berbeda-beda satu sama lain, sistem kipas (fan) dimana kabel dipusatkan pada ujung atas menara dan disebar sepanjang bentang pada gelagar, dan modifikasi sistem semi fan dimana kabel disebar pada bagian atas menara dan pada dek sepanjang bentang yang menghasilkan kabel tidak sejajar (Zadeh, 2012).
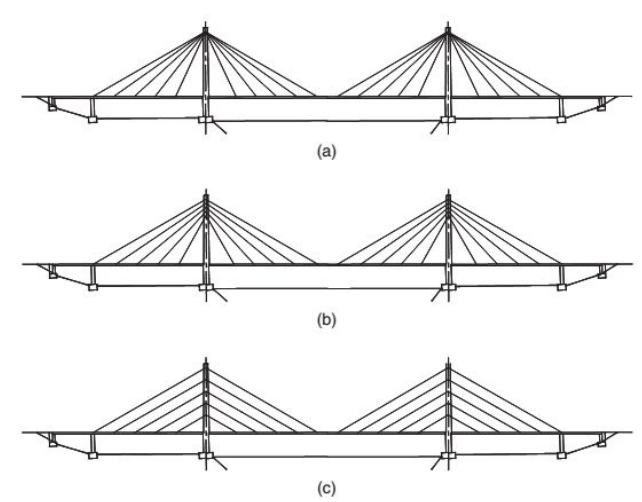

Gambar 2. Konfigurasi Kabel (a) Fan System, (b) Modified Fan System, (c) Harp System Sumber : (Parke \& Hewson, 2008)

Menara adalah komponen jembatan cable stayed yang berfungsi pendukung rangkaian kabel dan menyalurkan beban ke pondasi (Gambar 3). Desain menara menunjukkan nilai keindahan dari jembatan cable stayed, maka perancang harus memilih proporsi dan bentuk yang baik. Selain fungsi yang diatas, menara ini menahan gaya aksial dan momen yang cukup besar, hal ini tergantung kondisi tanah yang mendukungnya. Bahan konstruksi dibuat dari beton atau baja yang tergantung kondisi tanah dan kecepatan konstruksi yang diperlukan. (Mukhsin \& Ramdani, 2017).

Angkur adalah tempat ujung kabel dikaitkan ke penumpu. Angkur harus menyalurkan gaya kabel pada dek jembatan dan pylon. Secara umum tipe angkur yang digunakan pada jembatan cable stayed dibagi menjadi dua yaitu Angkur hidup yakni angkur yang terletak pada ujung kabel ketika dilakukan pemberian tegangan, biasanya pada menara jembatan; dan Angkur mati yakni angkur yang terletak pada ujung kabel ketika tidak dilakukan pemberian tegangan, biasanya pada dek jembatan (Kementrian, 2015). 


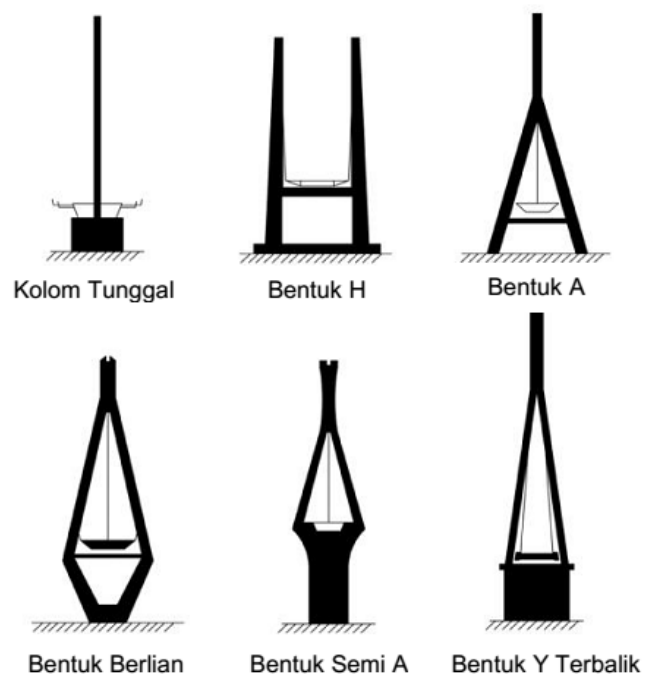

Gambar 3. Konfigurasi Menara Sumber : (Kementrian, 2015)

Bentuk gelagar jembatan cable-stayed yang sering digunakan ada dua jenis yaitu tipe pengaku baja (stiffening truss) dan tipe profil padat (solid web). Tipe pengaku baja memerlukan proses fabrikasi lebih kompleks, relatif sulit dalam perawatan dan mudah terpengaruh korosi sehingga jarang digunakan. Tipe profil padat terdiri atas gelagar pelat (plate girder) dan gelagar box (box girder), gelagar box memiliki kekakuan torsional lebih tinggi dibandingkan gelagar pelat sehingga cocok untuk jembatan yang mengalami torsi yang sangat besar. Selain itu pemilihan material untuk lantai jembatan tergantung dari parameter biaya.

\subsection{Analisis Statis dan Dinamis}

Perencanaan cable stayed dalam analisis statis dilakukan berdasarkan beberapa aspek yaitu lokasi jembatan, layout jembatan, sistem lantai jembatan, sistem menara jembatan, sistem kabel penggantung, beban jembatan, tahapan umum perencanaan, dan pemodelan analisis struktur. Lantai jembatan memiliki kekakuan yang dipengaruhi oleh dimensi penampang, maka untuk mendapatkan panjang segmen lantai digunakan perhitungan rasio kelangsingan antara tinggi dan jarak kabel penggantung dengan rasio 1/50 - 1/70. Rasio kelangsingan kabel back stay yang diikatkan pada perletakan diatas tanah sampai dengan rasio $1 / 100$.

Pemilihan bentuk menara berpengaruh pada defomasi sistem lantai jembatan yang kaku. Acuan awal dalam menentukan tinggi menara adalah $h=1 / 3$ bentang. Dalam menjaga perhitungan linier, lendutan tidak boleh melampaui batasan sebagai berikut: lendutan lantai akibat beban lalu lintas $\leq(1 / 400)$ L bentang utama dan lendutan menara akibat beban lalu lintas $\leq(1 / 400) \mathrm{h}$ tinggi menara. Batasan tersebut mengijinkan lendutan lebih besar untuk gelagar lantai dibandingkan gelagar kaku karena perletakan pegas cable stayed membuat gelagar menjadi lebih fleksibel. Keperluan kabel dan sistem kabel penggantung dipengaruhi oleh berat, tipe lantai dan cara pelaksanaan. Lantai beton perlu menggunakan banyak kabel dengan jarak 5-10 m.(Irawan \& Tristanto, 2011)

Analisis dinamis adalah metode analisis struktur dengan getaran gempa yang dimodelkan sebagai beban dinamis, diman beban yang arah dan besarnya berubah setiap waktu. Analsis dinamis yang dilakukan dalam penelitan ini adalah time history analysis yang cocok digunakan dalam menganalisis struktur yang tidak beraturan terhdap pengaruh gempa 
rencana. Pada analisis ini struktur yang di desain diberi percepatan pada permukaan tanah sesuai rekaman percepatan terhadap waktu dari data time history.

\section{METODOLOGI PENELITIAN}

Penelitian ini menggunakan model struktur jembatan cable stayed dengan menggunakan kabel sebagai elemen truss, menara sebagai elemen frame dan dek sebagai elemen frame kemudian dimodelkan konfigurasi struktur menara yang berbeda yaitu bentuk menara tipe A, menara tipe $\mathrm{H}$, menara tipe $\mathrm{Y}$ terbalik, menara bentuk berlian dan menara tipe $\mathrm{X}$. Analisis struktur menggunakan software CSIBridge v20.2.0.

\subsection{Model Struktur Jembatan}

Pada penelitian ini parameter yang dibuat tetap untuk semua variasi bentuk menara adalah tipe dan jumlah kabel, bentang jembatan, tipe pelat, dan luas permukaan menara. Data umum jembatan yang digunakan pada penelitian ini dapat dilihat pada Tabel 1 .

Tabel 1. Data Umum Jembatan

\begin{tabular}{ll}
\hline Nama & Uraian \\
\hline System konfigurasi & Jembatan cable stayed \\
\hline Panjang total & 804 $\mathrm{m}$ \\
\hline Konfigurasi bentang & Konfigurasi tiga bentang \\
\hline Panjang bentang & Bentang utama $=402 \mathrm{~m}$ \\
& Bentang samping = $01 \mathrm{~m}$ \\
\hline \multirow{2}{*}{ Tinggi menara } & Di atas deck =93 m \\
& Di bawah deck =31 m \\
\hline \multirow{2}{*}{ Jumlah Kabel } & Bentang utama =42 @ 9 m \\
\hline Tipe jalan & Bentang samping = 42 @ 9 m \\
\hline Tipe deck & $4 / 2 \mathrm{D} @ 3.5 \mathrm{~m}$ \\
\hline Tinggi deck & Concrete Flat Slab \\
\hline Lebar deck & $1,83 \mathrm{~m}$ \\
\hline
\end{tabular}

Modeling jembatan yang dianalisa dapat dilihat dari tampak samping seperti Gambar 4, tampak atas seperti Gambar 5 dan konfigurasi sebanyak 5 menara secara tiga dimensi dapat dilihat pada Gambar 6.

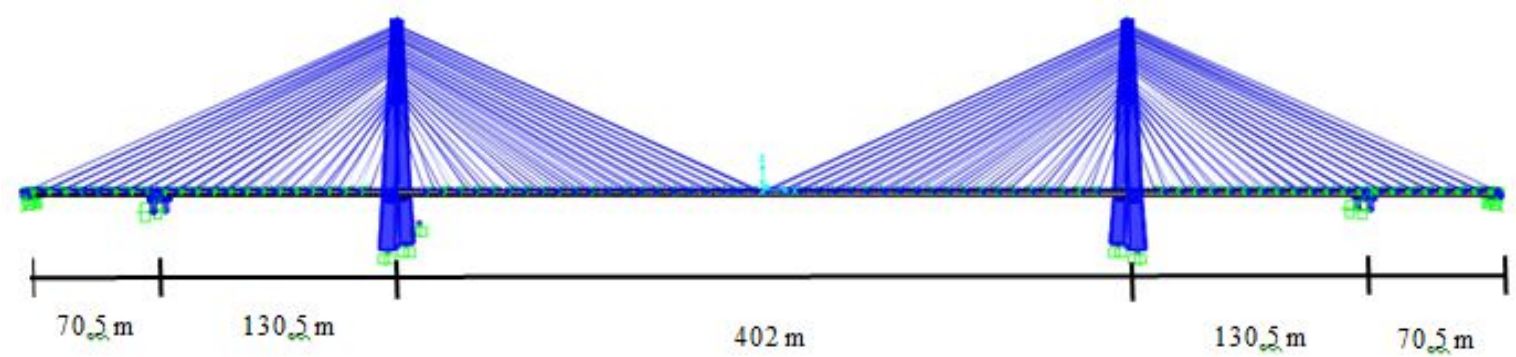

Gambar 4. Model Jembatan Tampak Samping

Gambar 5. Model Jembatan Tampak Atas 


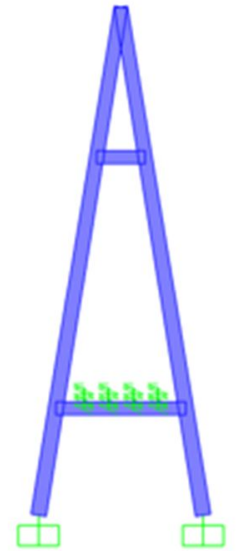

(a)

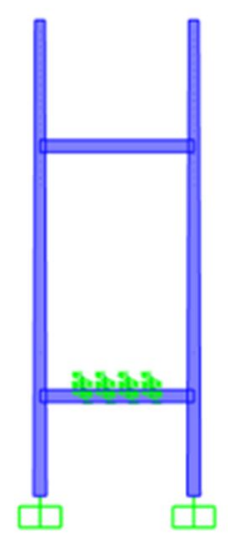

(b)

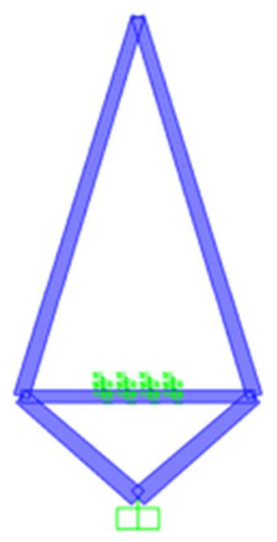

(c)

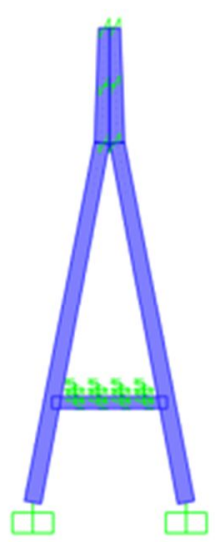

(d)

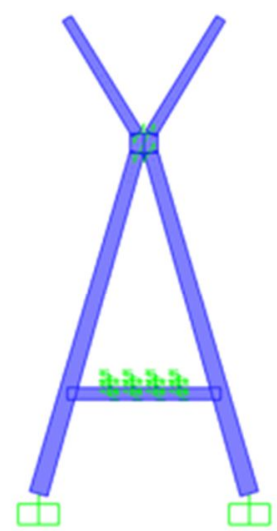

(e)

Gambar 6. Bentuk -Bentuk Menara yakni (a) Menara Tipe A, (b) Menara Tipe H, (c) Menara Tipe Berlian, (d) Menara Tipe Inverted Y, dan (e) Menara Tipe X

\subsection{Lokasi Penelitian}

Dalam studi kasus analisis ini, lokasi jembatan yang dianalisis di wilayah Kalimantan Timur tepatnya pada kota Balikpapan dengan koordinat lokasi latitude (-1.111416922) dan longitudinal (116.7290316) seperti di Gambar 7. Kalimantan merupakan area di Indonesia yang memiliki seismistis paling rendah dengan didominasi oleh aktivitas sesar. Oleh karena itu kalimantan bukan merupakan daerah yang bebas gempa bumi, dimana teridentifikasi tiga zona sesar utama dipulai kalimantan yakni sesar Tarakan, sesar mangkalihat, dan sesar maratus (Rusmilawati et al., 2019) dengan contoh kasus tanggal 20 Desember 2015, terjadi gempa dengan mangnitudo 6 di Tarakan dan 24 Juni 2016 terjadi juga gempa dengan mangnitudo 5,1 di barat daya Kalimantan. (Pustlitbang PUPR, 2017)

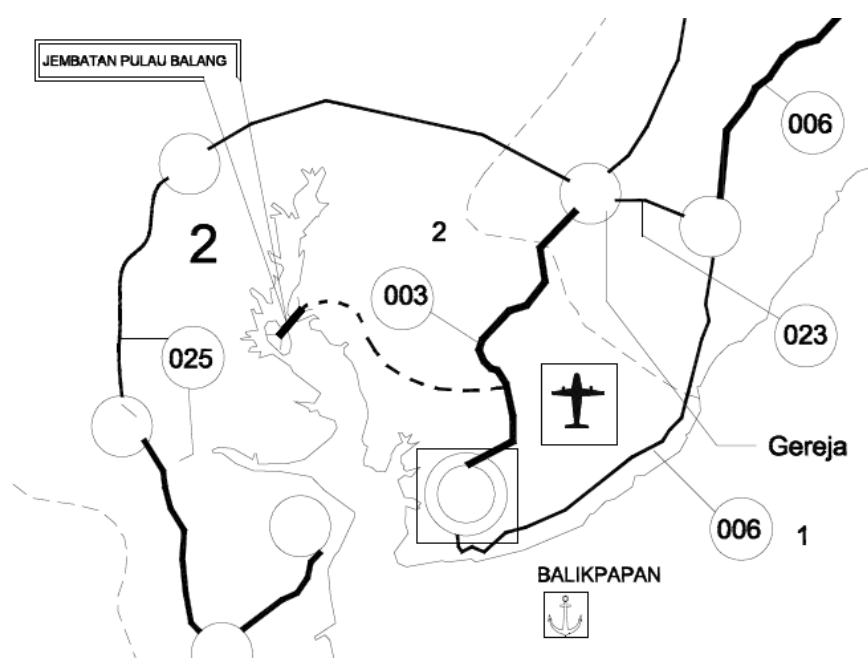

Gambar 7. Lokasi Jembatan Pulau Balang, Kalimantan Timur (Kementerian Pekerjaan Umum Direktorat Jenderal Bina Marga, 2014) 


\subsection{Data Perencanaan Gempa}

Penelitian menggunakan peta gempa dengan probabilitas terlampau $7 \%$ dalam 75 tahun. Faktor respon gempa diperoleh pada aplikasi yang dikembangkan oleh Pusat Jalan dan Jembatan (Pusjatan) untuk wilayah Balikpapan seperti respon spectrum pada gambar 7a. Penelitian menggunakan beban time historybeban Kobe Japan tepatnya di Takatoru Station 1995 Magnitude 6.9 SR. seperti gambar 7b dibawah ini. Pemilihan gempa Kobe dengan karakteristik geografinya meyerupai Indonesia menjadi dasar peneliti dengan beban gempa yang menyerupai gempa di Tarakan.

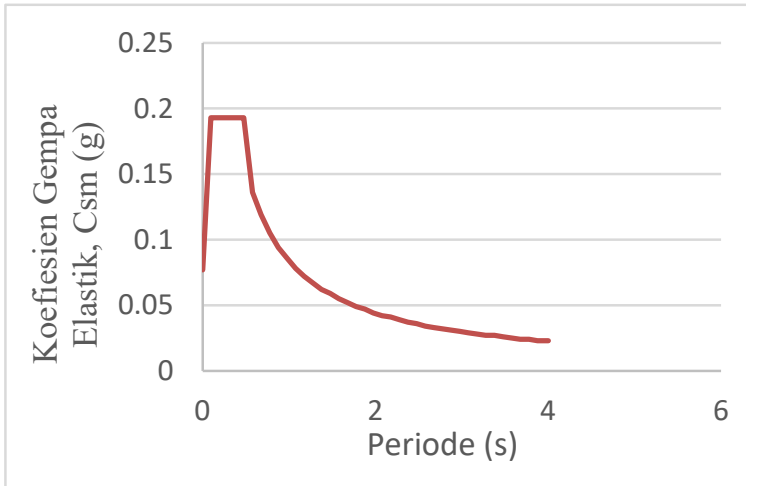

(a) Target Respon Spectrum

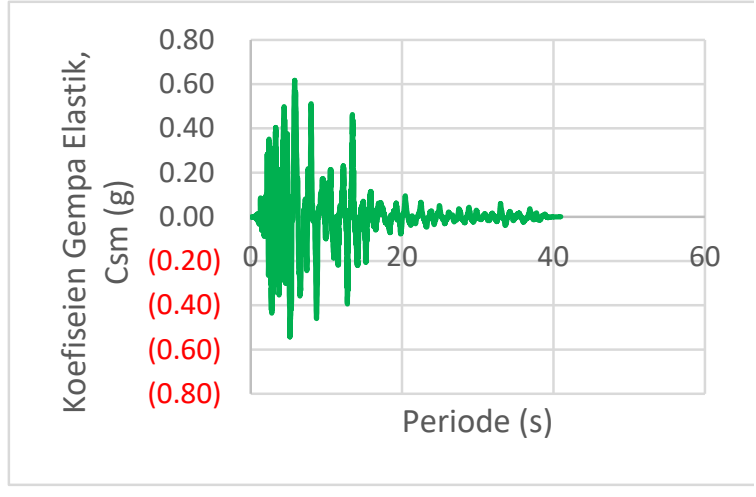

(b) Kobe Earthquake Time History

Gambar 8. Data Beban Gempa

\subsection{Data Penyelidikan Tanah}

Data Tanah yang digunakan pada analisis merupakan data sekunder dari Kementrian Pekerjaan Umum Direktorat jenderal Bina Marga Balai Besar Pelaksanaan Jalan Nasional VII Banjarmasin. Pengujian menggunakan nilai SPT sepanjang $40 \mathrm{~m}$ dibawah permukaan tanah dengan jumlah pengujian sebanyak delapan titik. Profil tanah dan Nilai SPT dapat dilihat pada Gambar 9.

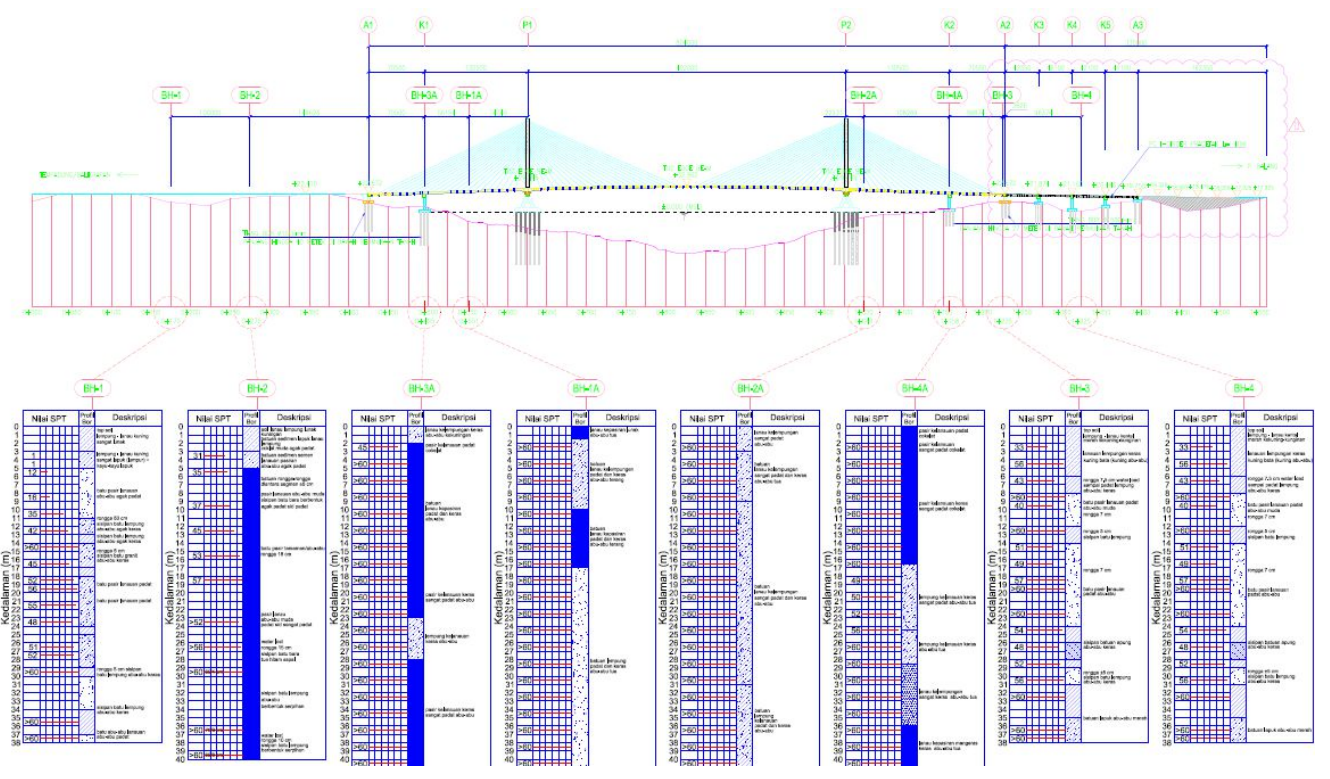

Gambar 9. Profil Tanah dan Nilai N-SPT di Lintasan Jembatan Sumber : (Kementerian Pekerjaan Umum Direktorat Jenderal Bina Marga, 2014) 


\section{HASIL DAN PEMBAHASAN}

\subsection{Pembebanan Struktur}

Pedoman pembebanan rencana yang digunakan mengacu pada perencanaan jembatan terhadap beban gempa (SNI 1725-2016.) Secara umum beban rencana tersebut adalah sebagai berikut

Aksi Tetap terdiri dari berat sendiri (MS) dan beban mati tambahan (MA). Beban sendirii merupakan beban gravitasi dari berat elemen struktur yang terdiri dari berat deck, berat menara, berat kabel dan berat pilar yang akan dihitung otomatis oleh program CSI Bridge 2019 dalam analisanya. Beban mati tambahan yang terjadi pada jembatan ada beban air hujan, beban parapet atau kerb, beban lapisan aspal dan overlay.

1. Beban air hujan = $=t_{\mathrm{h}} \times$ berat jenis air $=0,05 \mathrm{~m} \times 9,8 \mathrm{kN} / \mathrm{m}^{3}=0,49 \mathrm{kN} / \mathrm{m}^{2}$

2. Beban parapet atau kerb $=15 \mathrm{kN} / \mathrm{m}^{2}$

3. Beban lapisan aspal $=\mathrm{t}_{\mathrm{a}} \times$ berat jenis aspal $=0,25 \mathrm{~m} \times 22 \mathrm{kN} / \mathrm{m}^{3}=5,5 \mathrm{kN} / \mathrm{m}^{2}$

4. Beban trotoar = $t_{\mathrm{t}} \times$ berat jenis trotoar $=0,25 \times 24 \mathrm{kN} / \mathrm{m}^{3}=6 \mathrm{kN} / \mathrm{m}^{2}$

Beban tambahan yang bekerja pada lajur adalah beban air hujan, beban aspal dan overlay dan beban kerb yaitu sebesar $20,99 \mathrm{kN} / \mathrm{m}^{2}$. Sedangkan beban mati yang bekerja pada trotoar adalah beban air hujan, beban trotoar dan beban kerb yaitu sebesar $21,49 \mathrm{kN} / \mathrm{m}^{2}$.

Ada dua jenis beban lalu lintas yang dihitung yaitu beban lajur (TD) dan beban truk (TT). Beban lajur "D" terdiri atas beban terbagi rata (BTR) yang digabung dengan beban garis terpusat (BGT).

1. Beban Terbagi Rata (BTR)

Lebar jalur lalu lintas

Panjang bentang utama $\left(\mathrm{L}_{1}\right)$

$=17 \mathrm{~m}$

Panjang bentang samping pertama $\left(\mathrm{L}_{2}\right) \quad=130,5 \mathrm{~m}$

Panjang bentang samping kedua $\left(\mathrm{L}_{3}\right) \quad=70,5 \mathrm{~m}$

Panjang bentang rata-rata $\left(\mathrm{L}_{\mathrm{av}}\right) \quad=\frac{L_{1}+L_{2}+L_{3}}{3}=\frac{402+130,5+70,5}{3}=201 \mathrm{~m}$

Rata - rata panjang bentang $\left(\mathrm{L}_{\mathrm{E}}\right)=\sqrt{L_{a v} \times L_{\max }}=\sqrt{201 \times 402}=284,26 \mathrm{~m}$

Beban BTR pada $\mathrm{L}_{\mathrm{E}}>30 \mathrm{~m}$ TD $=9 \times\left(0,5+\frac{15}{L_{E}}\right)$

$$
=9 \times\left(0,5+\frac{15}{284,26}\right)=4,975 \mathrm{kPa}=4,975 \mathrm{kN} / \mathrm{m}^{2}
$$

2. Beban Garis Terpusat (BGT)

Beban garis terpusat berdasarkan SNI 1725-2016 mempunyai intensitas p sebesar 49 $\mathrm{kN} / \mathrm{m}$ (Badan Standardisasi Nasional, 2016). Besarnya BGT harus cukup untuk memberikan terjadinya interaksi antara kendaraan yang bergerak dengan jembatan yang dikalikan dengan faktor beban dinamis (Dinamic Load Allowance). Jembatan memiliki nilai DLA adalah 30\% sehingga beban BGT dihitunng sebesar

Beban BGT $\quad \mathrm{P}_{\mathrm{TD}}=(1+$ DLA $) \times \mathrm{p} \times$ lebar jalur 
Jumlah girder

Beban per girder BGT

$$
\begin{aligned}
& =(1+30 \%) \times 49 \times 17=1082,9 \mathrm{kN} \\
& =4 \\
& =1082,9 / 2=270,725 \mathrm{kN}
\end{aligned}
$$

3. Beban Truk (TT)

Beban truk " $\mathrm{T}$ " terdiri atas tiga gandar yang diletakkan pada beberapa posisi pada lajur lalu lintas rencana. Beban truk yang digunakan sebesar $500 \mathrm{kN}$ dengan dua kendaraan truk " $T$ " pada satu lajur lalu lintas rencana.

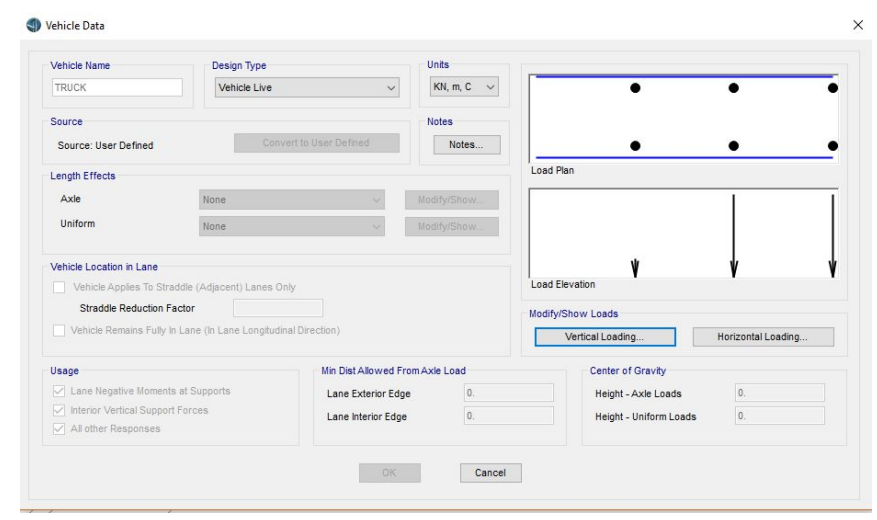

Gambar 10. Input Beban TT

Beban Rem (TB) diambil yang terbesar dari perhitungan berikut:

a. Beban gandar truk $\times 25 \%$

Beban untuk 2 jalur

b. Beban BTR

$$
\begin{aligned}
& =225 \mathrm{kN} \times 25 \%=56,25 \mathrm{kN} \\
& =56,25 \mathrm{kN} \times 2=112,5 \mathrm{kN} \\
& =\mathrm{q}_{\mathrm{td}} \times \text { panjang total } \times \text { lebar jalur } \\
& =4,975 \mathrm{kN} / \mathrm{m}^{2} \times 804 \times 17=67997,24 \mathrm{kN} \\
& =(500 \mathrm{kN}+67997,24 \mathrm{kN}) \times 5 \%=3424,86 \mathrm{kN}
\end{aligned}
$$

(Beban truk + Beban BTR ) $\times 5 \%$

Diambil beban akibat rem (TB) sebesar $3424,86 \mathrm{kN}$. Beban rem tersebut diditribusikan ke setiap titik pertemuan gelagar dan lantai jembatan dengan jumlah titik adalah 168 titik Gaya rem setiap titik $\left(\mathrm{T}_{\mathrm{TB}}\right)$ $=3424,86 / 168=20,39 \mathrm{kN}$

Beban angin yang bekerja pada jembatan menurut SNI 1725-2016 dibagi menjadi dua tipe yaitu beban angin pada struktur $\left(\mathrm{E}_{\mathrm{WS}}\right)$ dan beban angin pada kendaraan $\left(\mathrm{E}_{\mathrm{WL}}\right)$. Beban angin terjadi disebabkan oleh kecepatan angina rencana.

1. Kecepatan Angin Rencana

Jembatan terletak pada kondisi sub urban sehingga kecepatan rencana $\mathrm{V}_{0}$ diambil sebesar $17,6 \mathrm{~km} / \mathrm{jam}$ dengan ketinggian $\mathrm{Z}_{0}$ yaitu $1000 \mathrm{~mm}$. Data kecepatan angin pada elevasi $10000 \mathrm{~mm}\left(\mathrm{~V}_{10}\right)$ diatas permukaan tanah tidak ada sehingga diasumsikan $\mathrm{V}_{10}$ sebesar $90 \mathrm{~km} / \mathrm{jam}$. Ketinggian yang diukur dari muka air ke struktur jembatan (Z) adalah $32962 \mathrm{~mm}$. Maka kecepatan angin rencana adalah

$V_{D Z}=2,5 V_{0} \ln \left(\frac{Z}{Z_{0}}\right) V_{D Z}=2,5 \times 17,6 \times \frac{90}{90} \times \ln \left(\frac{32962}{1000}\right)=153,79 \mathrm{~km} / \mathrm{ham}$

2. Beban Angin pada Struktur ( $\left.\mathrm{E}_{\mathrm{ws}}\right)$

Beban angin struktur dibedakan menjadi dua yaitu beban angin tekan dan beban angin hisap.

a. Angin Tekan

Tekanan angin tekan dasar pada struktur $\left(\mathrm{P}_{\mathrm{B}}\right)$ adalah $0,0024 \mathrm{Mpa}$ 


$$
\begin{aligned}
& P_{D}=P_{B} \times\left(\frac{V_{D Z}}{V_{B}}\right)^{2}=0,0024 \times\left(\frac{153,79}{90}\right)^{2}=0,0070833 \mathrm{Mpa} \\
& E W_{S}=7,008 \mathrm{kN} / \mathrm{m}^{2} \times 8,5 \mathrm{~m}=59,57 \mathrm{kN} / \mathrm{m}
\end{aligned}
$$

b. Angin Hisap

Tekanan angin tekan hisap pada struktur $\left(\mathrm{P}_{\mathrm{B}}\right)$ adalah 0,0012 Mpa

$$
\begin{aligned}
& P_{D}=P_{B} \times\left(\frac{V_{D Z}}{V_{B}}\right)^{2}=0,0012 \times\left(\frac{153,79}{90}\right)^{2}=0,0035042 \mathrm{Mpa} \\
& E W_{S}=3,5004 \mathrm{kN} / \mathrm{m}^{2} \times 8,5 \mathrm{~m}=29,78 \mathrm{kN} / \mathrm{m}
\end{aligned}
$$

3. Beban Angin pada Kendaraan ( $\left.\mathrm{E}_{\mathrm{WL}}\right)$

Beban angin akibat tekanan angin pada kendaraan direncanakan sebagai tekanan menerus $\left(\mathrm{P}_{\mathrm{D}}\right)$ sebesar $1,46 \mathrm{~N} / \mathrm{mm}$ yang tegak lurus dan bekerja setinggi $(\mathrm{h}) 1800 \mathrm{~mm}$ di atas permukaan jalan. Jarak antara roda kendaraan (x) adalah $1750 \mathrm{~mm}$, sehingga beban angin akibat kendaraan adalah

$$
E_{W L}=\frac{0,5 \times h}{x} \times P_{D}=\frac{0,5 \times 1800}{1750} \times 1,46=0,75 \mathrm{~N} / \mathrm{mm}=0,75 \mathrm{kN} / \mathrm{m}
$$

\subsection{Beban Gempa dengan Metode Analisis Dinamik Time History}

Rekaman gerakan tanah akibat gempa yang diambil dari akseleogram Kobe Japan tepatnya di Takatoru Station 1995. Dalam analsiis ini redaman struktur yang diperhitungkan dapat dianggap 5\% dari redaman kritisnya. Pemasukan data rekaman sebagai beban gempa ini dilakukan menggunakan program CSI Bridge

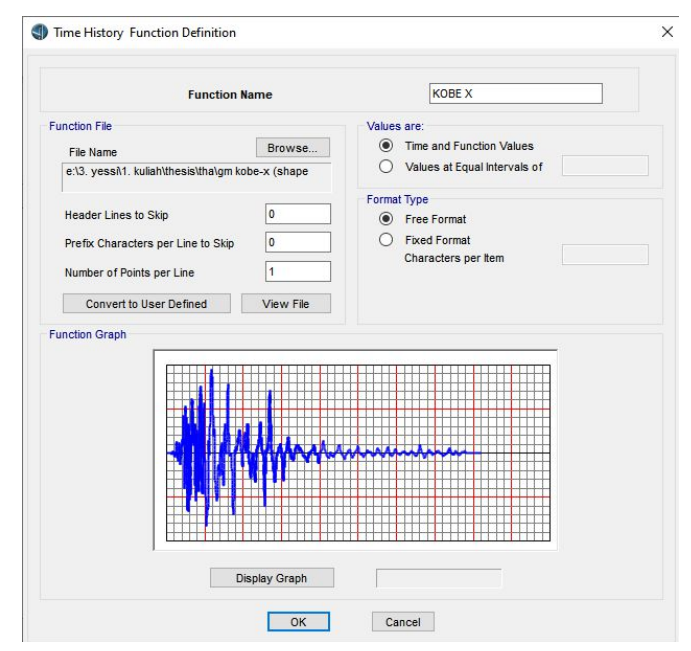

Gambar 11. Input Rekaman Gempa Kobe

\subsection{Perpindahan Menara}

Pada analisis didapatkan hasil perpindahan maksimum menara akibat gempa dari berbagai tipe menara yaitu menara bentuk A, menara bentuk berlian, menara bentuk Inverted Y dan menara bentuk X. Dari grafik dibawah ini didapatkan bahwa menara mengalami perpindahan secara tiga arah yaitu perpindahan secara longitudinal, perpindahan secara transversal, dan perpindahan secara vertikal 


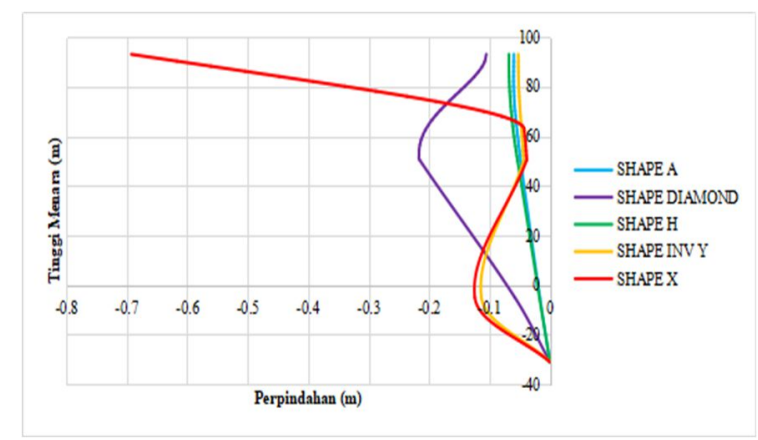

(a) Perpindahan Menara secara Longitudinal

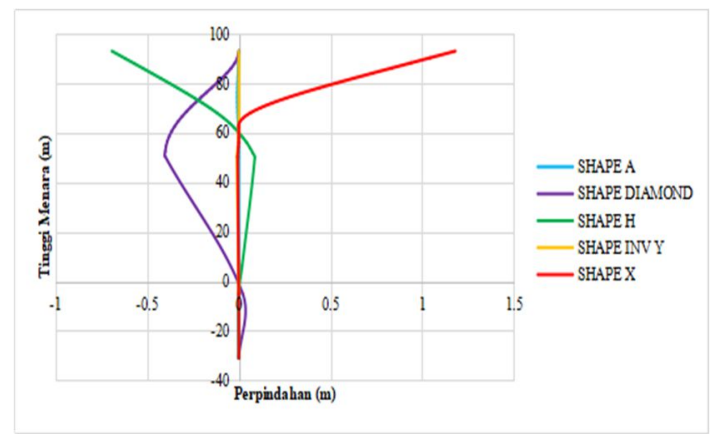

(b) Perpindahan Menara secara Transversal

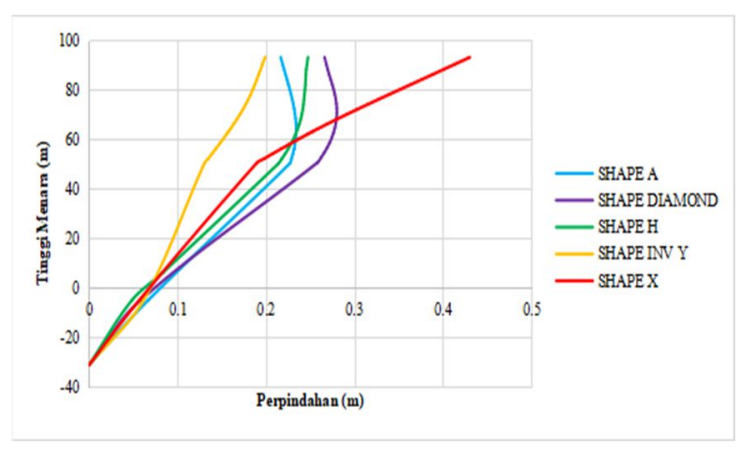

(c) Perpindahan Menara secara Vertikal

\section{Gambar 12. Hasil Analisis Nilai Perpindahan Menara}

Dilihat dari gambar 12.a bahwa ada tiga menara yang memiliki grafik hampir sama pada puncak menara yaitu menara tipe A, tipe $\mathrm{H}$, dan tipe Inverted $\mathrm{Y}$. Ketiga grafik menunjukan perpindahan yang nilainya yang lebih kecil dibandingkan menara tipe lain. Menara tipe berlian mengalami perpindahan yang besar karena menjauh menara dari pusat massa sehingga berkurangnya kestabilannya dan mengalami perpindahan yang besar dan menara yang mengalami perpindahan yang sangat signifikan adalah menara tipe $\mathrm{X}$

Berdasarkan gambar 12.b terdapat tiga menara yang mengalami garis berhimpitan yaitu menara tipe A, tipe Inverted $\mathrm{Y}$ dan tipe $\mathrm{X}$ dimana nilai perpindahannya sangat kecil dengan nilai kurang dari $1 \mathrm{~cm}$. Dari ketiga menara tadi, menara tipe $\mathrm{X}$ mengalami perpindahan yang besar pada puncak menara karena bentuk menara pada bagian atas menjauh dari pusat massa dan adanya gaya tarik dari kabel yang mempengaruhi perpindahan yang terjadi. Menara tipe $\mathrm{H}$ mengalami perpindahan yang cukup besar pada puncak menara kemudian perpindahan mengalami penurunan secara signifikan dimana pada ketinggian tersebut terdapat balok melintang pada menara.

Dilihat dari gambar 12.c terdapat persamaan dari kelima menara pada ketinggian $53 \mathrm{~m}$ yang merupakan batas adanya gaya tarik dari kabel, dimana grafik mengalami penurunan hingga dasar menara. Menara tipe Inverted Y mengalami perpindahan paling kecil dan menara tipe $\mathrm{X}$ yang mengalami perpindahan paling besar dengan nilai sebesar $43 \mathrm{~cm}$.

\subsection{Gaya Dalam Menara}

Berikut ini hasil dari gaya-gaya dalam yang dialami oleh menara yakni gaya aksial menara, gaya geser menara, gaya torsi menara, dan momen gaya menara. 


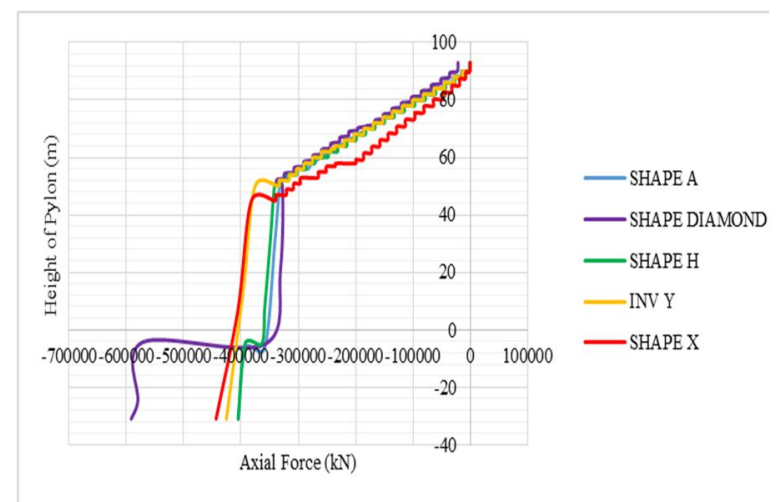

(a) Gaya Aksial Menara

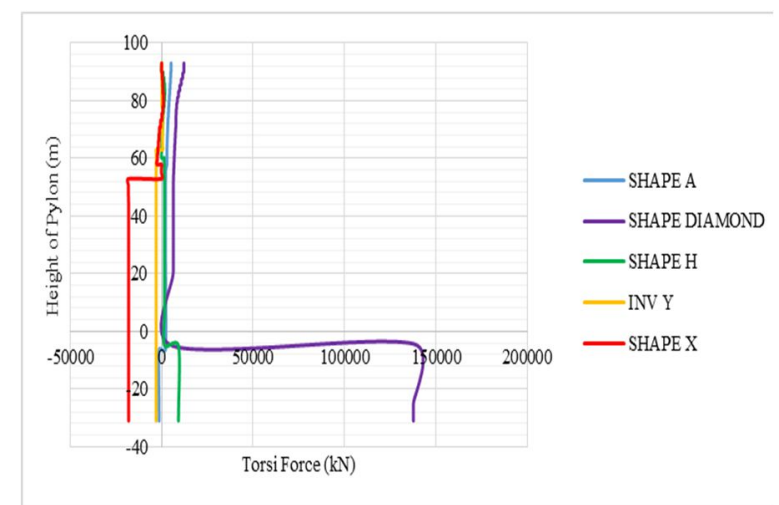

(c) Gaya Torsi Menara

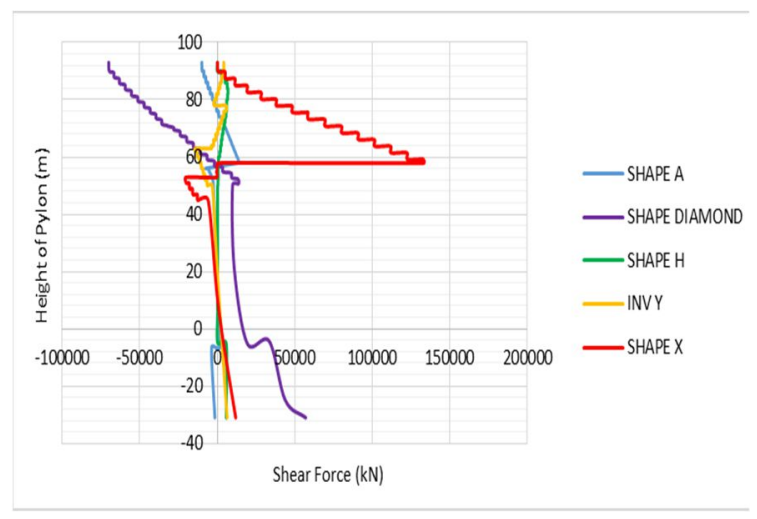

(b) Gaya Aksial Menara

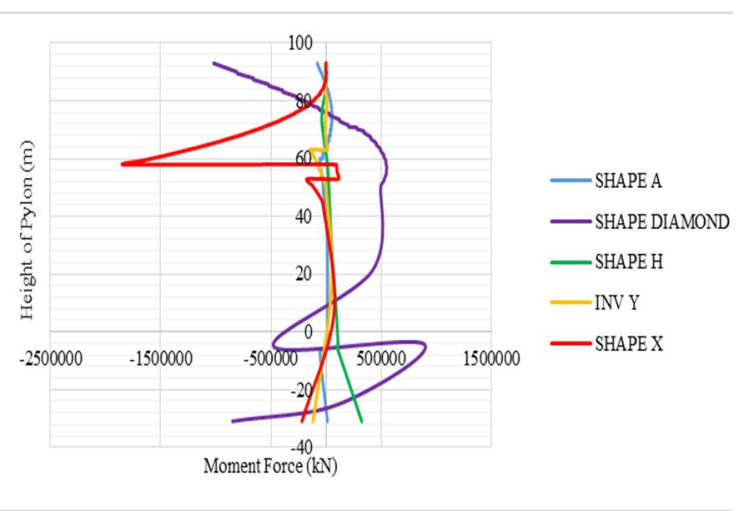

(d) Gaya Moment Menara

\section{Gambar 13. Hasil Analisis Gaya Dalam Menara}

Dilihat dari gambar 13(a) bahwa menara yang memiliki gaya aksial terkecil adalah menara tipe tipe $\mathrm{H}$ diikuti menara tipe $\mathrm{A}$, tipe Inverted $\mathrm{Y}$, tipe $\mathrm{X}$ dan menara tipe berlian. Setiap menara memiliki grafik yang hampir sama dimulai dari ketinggian $93 \mathrm{~m}$ dengan perubahan gaya tiap $2 \mathrm{~m}$ akibat gaya tarik kabel sehingga gaya aksial semakin membesar hingga batas kabel di ketinggian $53 \mathrm{~m}$. Setelah itu perubahan gaya aksial yang terjadi lebih konstan dan mengalami peningkatan gaya aksial saat ketinggian $5 \mathrm{~m}$ dibawah garis nol. Hal ini terjadi karena ada balok melintang pada setiap menara yang ikut menahan gaya tekan dari pelat lantai yang bertumpuan pada balok. Perbedaan gaya aksial yang paling menonjol dari semua tipe menara adalah tipe menara berlian.

Berdasarkan gambar 13(b) bahwa gaya geser yang dialami masing-masing menara semakin besar dimulai dari puncak menara hingga ketinggian $53 \mathrm{~m}$. Hal ini diakibatkan adanya gaya tarik dari kabel yang dibebankan terhadap menara sehingga gaya geser yang terjadi semakin meningkat.

Berdasarkan gambar 13(c) didapatkan ada tiga menara yang mengalami gaya torsi yang kecil pada puncak menara yakni menara tipe Inverted $\mathrm{Y}$, tipe $\mathrm{H}$ dan tipe $\mathrm{X}$ dimana ketiganya memiliki nilai yang berhimpitan. Menara tipe A memiliki nilai gaya torsi lebih besar dari tiga menara sebelumnya pada puncak menara kemudian grafik berhimpitan dengan menara tipe $\mathrm{H}$ dan mengalami peningkatan sedikit pada daerah yang terdapat balok melintang. Menara tipe berlian memiliki gaya torsi yang paling menonjol dengan nilai torsi yang paling besar pada puncak menara dengan nilai yang menurun dan mengalami gaya torsi yang 
meningkat pada ketinggian $-5 \mathrm{~m}$, hal ini terjadi karena posisi menara dari menyatu dipuncak dan melebar kesamping.

Berdasarkan gambar 13(d) masing-masing menara memiliki grafik dengan bentuk yang berbeda-beda, dimana terlihat dari grafik bahwa menara yang memiliki gaya moment yang paling kecil pada menara tipe A dan menara $\mathrm{X}$ memiliki nilai moment yang terbesar. Menara tipe berlian memiliki grafik yang bentuknya seperti S dimana gaya momennya besar pada puncak menara kemudian mengalami penurunan hingga ketinggian $53 \mathrm{~m}$ pada batas kabel dan mengalami nilai konstan, setelah itu terjadi peningkatan dan penurunan yang drastis hingga dasar menara karena tumpuan dasar pada menara berlian hanya satu sedangkan menara lain tumpuan dasarnya ada dua.

\subsection{Analisis Konfigurasi Menara Cable Stayed Bridge}

Hasil analisis perpindahaan menara ditunjukkan pada tabel 2 bahwa menara yang paling besar perpindahannya dilihat dari sisi vertikal, transversal dan longitudinal adalah menara tipe X. Menara yang mengalami perpindahan minimum secara vertikal adalah menara Inverted $\mathrm{Y}$, sedangkan menara yang mengalami perpindahan secara transversal dan longitudinal yang memiliki nilai minimum adalah menara dengan tipe $\mathrm{A}$.

Tabel 2. Perbandingan Perpindahan Menara

\begin{tabular}{lccc}
\hline \multirow{2}{*}{ Menara } & \multicolumn{3}{c}{ Perpindahan (m) } \\
\cline { 2 - 4 } & Vertikal & Transversal & Longitudinal \\
\hline Shape A & 0.234 & 0.008 & 0.060 \\
\hline $\begin{array}{l}\text { Shape } \\
\text { berlian }\end{array}$ & 0.280 & 0.402 & 0.217 \\
\hline Shape H & 0.247 & 0.691 & 0.068 \\
\hline Shape Inv Y & 0.199 & 0.010 & 0.113 \\
\hline Shape X & 0.430 & 1.180 & 0.692 \\
\hline
\end{tabular}

Selain perpindahan menara, gaya-gaya dalamnya yang dihasilkan dapat dibandingkan satu sama lain. Gaya-gaya dalam yang dibandingkan adalah gaya aksial, gaya torsi, gaya geser dan gaya moment. Berdasarkan tabel 3 dibawah ini maka dilihat menara yang mengalami gaya aksial paling besar adalah menara tipe berlian selanjutnya diikuti menara tipe $\mathrm{X}$, menara tipe Inverted Y, dan menara tipe A. Menara dengan gaya aksial terkecil adalah menara tipe $\mathrm{H}$. Menara yang memiliki gaya torsi yang paling besar adalah menara tipe $\mathrm{X}$ kemudian diikuti menara tipe berlian, menara tipe A, dan menara tipe tipe Inverted Y. Menara dengan torsi paling kecil ada pada menara tipe $\mathrm{H}$. Gaya geser yang paling besar yang dialami oleh menara adalah menara tipe berlian sedangkan menara yang mengalami gaya geser paling kecil adalah menara tipe Inverted Y. Menara yang mengalami moment paling besar adalah menara tipe X. Setelah itu diikuti oleh menara tipe berlian, menara tipe H, menara tipe Inverted $\mathrm{Y}$ dan menara yang paling kecil nilai momentnya adalah menara tipe A.

Tabel 3. Perbandingan Gaya-Gaya Dalam Menara

\begin{tabular}{lllll}
\hline \multirow{2}{*}{ Menara } & \multicolumn{4}{l}{ Gaya-gaya dalam $(\mathrm{kN})$} \\
\cline { 2 - 5 } & Aksial & Torsi & Geser & Moment \\
\hline Shape A & 404726.600 & 14306.696 & 5202.110 & 78780.258 \\
\hline Shape berlian & 591297.616 & 70065.582 & 137715.966 & 1019105.380 \\
\hline
\end{tabular}




\begin{tabular}{lllll}
\hline \multirow{2}{*}{ Menara } & \multicolumn{4}{l}{ Gaya-gaya dalam $(\mathrm{kN})$} \\
\cline { 2 - 5 } & Aksial & Torsi & Geser & Moment \\
\hline Shape H & 363838.094 & 6840.077 & 9197.229 & 324266.467 \\
\hline Shape Inv Y & 425286.396 & 14235.993 & 2967.257 & 142751.723 \\
\hline Shape X & 443365.694 & 133131.126 & 18202.510 & 1833740.310 \\
\hline
\end{tabular}

\section{KESIMPULAN}

Berdasarkan hasil analisis pengaruh konfigurasi menara pada jembatan cable stayed, perpindahan menara dipengaruh oleh kondisi semakin geometri menara menjauh gelagar dan puncak menara yang tidak menyatu maka semakin besar perpindahan yang dialami menara. Menara yang mengalami perpindahan minimum adalah menara Inverted $\mathrm{Y}$ yakni $1 \mathrm{~cm}$ secara transversal dengan perpindahan menara yang diijinkan sebesar $23 \mathrm{~cm}$. Hasil analisis gaya dalam menara yang mengalami gaya aksial dan torsi terkecil adalah menara tipe $\mathrm{H}$, menara yang mengalami gaya geser terkecil adalah menara tipe Inverted $\mathrm{Y}$ dan menara yang mengalami gaya moment terkecil adalah menara tipe A. Berdasarkan hasil analisis gaya dalam menyatakan bahwa semakin banyak tarikan kabel yang ditopang menara, semakin sedikit tumpuan pada menara dan geometri pada puncak menara yang tidak menyatu maka semakin besar gaya-gaya dalam yang dialami menara. Pemilihan bentuk menara diperhatikan dari gaya-gaya dalam menara untuk menahan gaya gempa dan perpindahan pada pelat lantai yang relatif kecil. Menara yang mengalami gaya-gaya dalam yang minimum yang dapat direkomendasi untuk digunakan pada jembatan cable stayed adalah menara tipe A, menara tipe $\mathrm{H}$ dan menara tipe Inverted Y.

\section{UCAPAN TERIMAKASIH}

Ucapan terima kasih penulis persembahkan kepada orang tua, kakak dan adik yang telah memberikan dukungan dan doa kepada penulis selama melakukan penelitian ini. Terima kasih pula kepada teman-teman Teknik Sipil 2013 Universitas Gunadarma dan dosen jurusan Teknik Sipil atas bimbingan dan ilmu yang diberikan selama perkuliahan.

\section{DAFTAR PUSTAKA}

Badan Standardisasi Nasional. (2016). SNI 1725:2016 Pembebanan untuk Jembatan.

Hararwala, H., \& Maaru, S. (2016). Effect of the Different Shapes of Pylons on the Dynamic Analysis of Cable Stayed Bridge using SAP 2000. International Journal for Scientific Research \& Development, 3(11), 411-414.

Irawan, R., \& Tristanto, L. (2011). Perencanaan Teknis Jembatan Cable Stayed (Cetakan ke). Kementerian Pekerjaan Umum Badan Penelitian dan Pengembangan Pusat Penelitian dan Pengembangan Jalan dan Jembatan.

Kementerian Pekerjaan Umum Direktorat Jenderal Bina Marga, B. B. P. J. N. V. B. (2014). Gambar Rencana Konstruksi Proyek Jembatan Pulau Balang Bentang Panjang Kalimantan Timur.

Kementrian, P. U. dan P. R. (2015). Pedoman Perencanaan Teknis Jembatan Beruji Kabel.

Mukhsin, M., \& Ramdani, Y. (2017). Optimasi Sistem Struktur Cable Stayed Akibat Beban Gempa. Jurnal Siliwangi, 3(1), 156-160.

Ohorella, S., \& Harsoyo. (2017). Analisis Kestabilan Cable Stayed Bridge Akibat Pengaruh Rasio Lebar Terhadap Bentang Jembatan. Jurnal Teknisia, 22(2), 359-371.

Parke, G., \& Hewson, N. (2008). ICE Manual of Bridge Engineering Edited (Second Edi). Thomas Telford Publishing.

Pustlitbang PUPR. (2017). Buku Sumber dan Bahaya Gempa Indonesia Tahun 2017 (M. T. Prof. Ir. Masyhur Irsyam, MSE, Ph.D. Prof. Sri Widiyantoro, M.Sc, Ph.D. Dr. Danny Hilman Natawidjaja Dr. Irwan Meilano, ST, M.Sc. Ariska Rudyanto, S.Si, Dipl.Tsu, Msc. Dr. Sri Hidayati Dr. Wahyu Triyoso Dr. Nuraini Rahma Hanifa Dr. Didiek Djarwadi Ir. Lut (ed.)). Pusat Penelitian dan 
Pengembangan Perumahan dan Permukiman Badan Penelitian dan Pengembangan Kementerian Pekerjaan Umum dan Perumahan Rakyat.

Rusmilawati, D., Lepong, P., \& Hendrawanto, B. (2019). Studi Mekanisme Sumber Gempa Bumi di Wilayah Kalimantan Berdasarkan Gerak Awal Gelombang P. Jurnal Geosains Kutai Basin, 2.

Shah, S. G., Desai, J. A., \& Solanki, C. H. (2010). Effect of Pylon Shape on seismic response of Cable stayed bridge with soil structure interaction. International Journal of Civil and Struntural Engineering, 1(3), 667-682.

Zadeh, O. S. (2012). Comparison Between Three Types of Cable Stayed Bridges Using Structural Optimization. Electronic Thesis and Dissertation Repository., 897(October). 